\title{
Bacterial gill disease of salmonids; relationship between the severity of gill lesions and bacterial recovery
}

\author{
V. E. Ostland ${ }^{1}$, H. W. Ferguson ${ }^{1}$, J. F. Prescott ${ }^{2}$, R. M. W. Stevenson ${ }^{3}$, I. K. Barker ${ }^{1}$ \\ ${ }^{1}$ Department of Pathology, ${ }^{2}$ Department of Veterinary Microbiology and Immunology, ${ }^{3}$ Department of Microbiology, \\ University of Guelph, Guelph, Ontario, Canada N1G 2W1
}

\begin{abstract}
Thirteen naturally occurring outbreaks of bacterial gill disease (BGD) affecting commercially reared salmonids in Ontario (mainly rainbow trout, Oncorhynchus mykiss) were examined histologically and bacteriologically. Bacteria recovered from healthy and diseased gills were enumerated, and the severity of the lesions from each outbreak was graded based on the histopathological changes. A positive correlation was found between the presence of gill lesions and the number of bacteria recovered from diseased gills. Clinically healthy rainbow trout had $4.95 \times 10^{3}$ colony forming units (CFU) per g of gill tissue and were histologically normal. The mean of the total yellow pigmented bacteria (YPB) recovered from healthy gills was $0.73 \times 10^{3} \mathrm{CFU} \mathrm{g}^{-1}$ with the YPB accounting for roughly $15 \%$ of the total recovered. During BGD, a significant increase was observed in the total aerobic, total YPB, and percent YPB from diseased gills. Mild outbreaks of BGD displayed limited lamellar epithelial and chloride cell hypertrophy and had, on average, $1.50 \times 10^{4} \mathrm{CFU} \mathrm{g}^{-1}$ gill tissue. Moderate outbreaks of BGD, associated with $9.57 \times 10^{4} \mathrm{CFU} \mathrm{g}{ }^{-1}$, displayed increased evidence of lamellar epithelial and chloride cell degeneration, necrosis, and exfoliation with moderate epithelial hyperplasia. Severe BGD had $3.91 \times 10^{6} \mathrm{CFU} \mathrm{g}{ }^{-1}$ gill tissue and displayed extensive lamellar epithelial hyperplasia and fusion. The mean of the total YPB recovered from gills from 13 outbreaks was $12.71 \times 10^{5} \mathrm{CFU} \mathrm{g}^{-1}$; the YPB accounted for approximately $35 \%$ of the total bacteria recovered, and are considered to be the most significant isolates for most outbreaks in Ontario hatcheries. Statistical analysis on the severity of lesions and bacterial recovery indicated a strong association between the severity of lesions and the presence of filamentous bacteria.
\end{abstract}

\section{INTRODUCTION}

Bacterial gill disease $(B G D)$ is the most serious problem affecting intensively cultured salmonids in Ontario hatcheries (Daoust \& Ferguson 1983). Although no specific isolate is common among all BGD outbreaks, BGD is associated with large numbers of filamentous, yellow pigmented bacteria (YPB) on the surface of the gills (Amend 1982). YPB are also however, commonly recovered from water and soil, as well as from healthy fish epithelium, including the gills (Christensen 1977. Horsley 1977, Holmes et al. 1984).

The severity of BGD is often associated with the extent of epithelial hyperplasia and lamellar fusion (Daoust \& Ferguson 1986). These changes have been recognized as the most common lesions seen in natur- ally occurring outbreaks of BGD. It has also been recognized that a relationship exists between the severity of the gill lesions and the numbers of filamentous bacteria seen on histology (Wood \& Yasutake 1957. Daoust \& Ferguson 1983). At the diagnostic level, however, it has been our experience that the mere presence of bacteria in wholemounts does not always correlate with the histological changes observed, i.e. large numbers of bacteria are occasionally accompanied by few gill lesions and vice versa.

There is virtually no work that attempts to assess and grade gill lesions and to correlate these with bacterial recovery. Accordingly, in this study the histopathology of BGD affecting cultured salmonids in Ontario is described, graded, and correlated with quantitative studies on the microflora. In addition, we sought to 
establish whether YPB are as commonly associated with BGD in Ontario hatcheries as they are reported to be elsewhere (Wakabayashi et al. 1980, Farkas 1985).

\section{MATERIALS AND METHODS}

History of outbreaks. Thirteen separate BGD outbreaks were examined among intensively cultured salmonids from 10 farms in Ontario (mainly rainbow trout, Oncorhynchus mykiss). Fish were submitted for diagnosis after an increase in the daily mortality and evidence of respiratory distress (i.e. flared opercula, laboured breathing, grossly swollen gills) was noted. The clinical histories were obtained at submission; from each outbreak a gross description was recorded and whole-mounts of affected gill tissue were examined microscopically. A tentative diagnosis of BGD was made on the basis of the presence of filamentous bacteria associated with the gills, regardless of whether or not architectural changes were observed (a filamentous bacterium was defined as one which was approximately 6 times as long as it was wide). If a positive diagnosis was made, several moribund fish were arbitrarily selected for further examination.

Histopathology. A total of 72 fish were sampled during the study, with the number of fish sampled per outbreak being as follows: Outbreak $\mathrm{A}=5, \mathrm{~B}=2, \mathrm{C}=$ 2, $\mathrm{D}=6, \mathrm{E}=6, \mathrm{~F}=10, \mathrm{G}=6, \mathrm{H}=5, \mathrm{I}=6 \mathrm{~g}, \mathrm{~J}=6, \mathrm{~K}=2$, $\mathrm{L}=10, \mathrm{M}=6 \mathrm{fish}$. The fish were killed by an overdose of tricaine methanesulfonate (MS-222, Sandoz Ltd.), blotted dry, and weighed to the nearest gram. For histological assessment of the gill tissue, the first gill arch (left side) of each fish was removed, placed in Bouin's fixative for $24 \mathrm{~h}$, then transferred to $70 \%$ isopropyl alcohol. The remaining tissues from fish within each outbreak were also fixed for histological examination. All tissues were routinely processed to paraffin wax, sectioned at $5 \mu \mathrm{m}$, and stained with hematoxylin and eosin (H\&E) and Periodic acid-Schiff (PAS).

Bacteriology. The remaining gill arches from each fish within an outbreak were excised, either processed as individual arches (Outbreaks B, C, E, F, L, M) or pooled (Outbreaks $A, D, G, H, I, J, K$ ), and weighed to the nearest $0.01 \mathrm{~g}$. The gills were placed in a sterile plastic bag containing $5 \mathrm{ml}$ of sterile $0.1 \mathrm{M}$ phosphate buffered saline (PBS, $\mathrm{pH} 7.4$ ) and manually crushed until only the cartilaginous arch remained. Serial 10fold dilutions of the tissue slurry were prepared in PBS and $20 \mu \mathrm{l}$ aliquots were spread onto single replicates of Cytophaga agar containing $1.5 \%$ agar $\left(1.5 \% \mathrm{CA}_{\text {; }}\right.$ Anacker \& Ordal 1959) and incubated aerobically at $10^{\circ} \mathrm{C}$ for $7 \mathrm{~d}$. The total aerobic bacteria and total YPB (both expressed per $g$ wet gill tissue) were enumerated by plate count for each outbreak. Plate counts were obtained by counting the dilution which yielded 20 to 200 colony forming units (CFU's). Total aerobic bacteria and total YPB $\mathrm{g}^{-1}$ gill tissue were calculated as follows:

$\left\{\mathrm{a} / 20 \mu \mathrm{l} \times 1000 \mu \mathrm{l} / 1 \mathrm{ml} \times 10^{\mathrm{b}}\right) /$ gill weight $(\mathrm{g})$.

where $\mathrm{a}=$ number of CFU's counted from that dilution and $b=$ dilution from which count was obtained.

From 9 outbreaks, 18 YPB strains were selected for further study, based on colony morphology. All were subcultured and stored in CA stabs containing $0.4 \%$ agar at $4{ }^{\circ} \mathrm{C}$ until required. The YPB were characterized according to the following criteria of Holmes et al. (1984) using the methods of Ostland et al. (1989): Gram reaction, cell morphology, flagellar and gliding motilify, presence of flagella, fermentation in glucose OF medium, oxidase and catalase production, and penicillin susceptibility.

Six rainbow trout from each of 6 commercial trout operations in Ontario were also sampled to quantify the normal aerobic microflora of healthy gills. Fish were selected from tanks experiencing low to no mortalities. All fish from each farm were killed as described above, placed in sterile plastic bags and transported to the laboratory on ice. Bacteriological examination was performed within 4 to 6 h of collection. Gills from a given farm were pooled and the total aerobic and total YPB were enumerated on $1.5 \%$ CA as described above.

Assessment of severity of microscopic lesions. One section from the first gill arch of each fish from each outbreak was examined histologically. A method was devised to subjectively rate the distribution of fusion, severity of hyperplasia, and the presence of filamentous bacteria in section. The microscopic changes were used to determine whether the severity of the gill lesions was related to the number of bacteria recovered from the gills.

Fusion was defined as the attachment and adhesion of one or more epithelial cell(s) of adjacent lamellae resulting in the occlusion of the interlamellar space. Hyperplasia was defined as an increase in the number of epithelial cell layers on the gill lamellae which are normally 1 to 2 cells thick (Laurent 1984). Epithelial proliferation, extending from the base of the interlamellar space of adjacent lamellae, which gave an appearance of 'fusion' due to progressive hyperplasia, was considered as fusion rather than hyperplasia for the purpose of this study. The histological criteria were scored as follows:

Distribution of fusion: 0 none $=$ no fusion evident; 1 mild = multifocal involving few $(1 \leq 25 \%)$ filaments; 2 moderate $=$ multifocal involving several $(26 \leq 50 \%)$ filaments; 3 marked = diffuse involving majority ( $\geq 51 \%$ of the filaments). Involvement of hyperplasia: 0 none $=$ no hyperplasia evident $;$ mild $=$ multifocal 
involving few $(1 \leq 25 \%)$ filaments; 2 moderate = multifocal involving several $(26 \leq 50 \%)$ filaments; 3 marked $=$ multifocal to diffuse involving majority $(\geq 51 \%)$ of filaments. Histological presence of filamentous bacteria: 0 none $=$ no bacteria evident; $1 \mathrm{few}=$ filamentous bacteria present on few $(1 \leq 25 \%)$ filaments; 2 some = filamentous bacteria present on several $(26 \leq 50 \%)$ filaments; 3 many = filamentous bacteria present on majority $(\geq 51 \%)$ of filaments. These scores were compared to the number of bacteria recovered per $\mathrm{g}$ wet gill tissue on $1.5 \% \mathrm{CA}$.

Other organ systems examined histologically included eye, spinal cord, heart, kidney, liver, spleen, stomach and intestine, pseudobranch, muscle and skeleton, non-branchial integument, and thymus.

Microscopic lesions compared to bacterial recovery. To provide a summary comparison between the microscopic lesions and the number of bacteria recovered from the gills, the lesion scores for each criterion (fusion, hyperplasia, and histological presence of bacteria) from each fish within an outbreak were summed, and the mean derived. These mean lesion scores were then summed to give an index of the severity of lesions for each outbreak. Outbreaks which had a lesion index greater than or equal to 6.00 were arbitrarily classified as severe, those lesion indices ranging from 3.00 to 5.99 were classified as moderate, and outbreaks with a lesion index less than or equal to 2.99 were considered mild. The mean of the total bacteria recovered from outbreaks with equivalent lesion index ranges were used to grade each outbreak.

Statistical analysis of microscopic assessment. The mean of the histological gill scores and the mean bacterial count (from outbreaks with individually processed gill arches) or the mean histological gill scores and total bacterial count (from outbreaks with pooled gill arches) were used for statistical analysis. Spearman correlation coefficients were calculated between each of the histological criteria (distribution of fusion, involvement of hyperplasia, histological presence of bacteria) and the total aerobic bacteria recovered from diseased gills using an SAS statistical package at the University of Guelph, Ontario (SAS Institute Incorporated 1985 ).

\section{RESULTS}

\section{Bacteriology}

The means of the total aerobic bacteria and the total YPB from healthy rainbow trout gills were $4.95 \times 10^{3}$ and $0.73 \times 10^{3} \mathrm{CFU} \mathrm{g}^{-1}$, respectively. The YPB constituted $15 \%$ of the total bacteria recovered (Table 1 ). During BGD, however, the mean total bacterial count
Table 1. Oncorhynchus mykiss. Total aerobic bacteria and total yellow pigmented bacteria (YPB) recovered from healthy rainbow trout gills (Farm) and salmonid gills with BGD (Outbreak). Values expressed as CFU $\mathrm{g}^{-1}$ wet gill tissue on Cytophaga agar

\begin{tabular}{|c|c|c|c|}
\hline Status & $\begin{array}{c}\text { Total } \\
\text { bacteria }\end{array}$ & $\begin{array}{l}\text { Total } \\
\text { YPB' }\end{array}$ & $\begin{array}{c}\text { Percent } \\
\text { YPB }\end{array}$ \\
\hline \multicolumn{4}{|c|}{ Farm $\left(\times 10^{3}\right)$} \\
\hline 1 & 4.26 & 0.89 & 21.2 \\
\hline 2 & 2.82 & 0.30 & 10.5 \\
\hline 3 & 4.89 & 0.59 & 12.1 \\
\hline 4 & 3.80 & 0.48 & 12.5 \\
\hline 5 & 5.01 & 1.05 & 20.8 \\
\hline 6 & 8.91 & 1.10 & 12.5 \\
\hline Mean & 4.95 & 0.73 & 14.9 \\
\hline $\mathrm{SD}$ & 0.21 & 0.32 & 4.8 \\
\hline \multicolumn{4}{|c|}{ Outbreak $\left(\times 10^{5}\right)$} \\
\hline A & 45.30 & 21.97 & 48.5 \\
\hline $\mathrm{B}$ & 91.40 & 48.90 & 53.5 \\
\hline $\mathrm{C}$ & 11.90 & 7.37 & 61.9 \\
\hline $\mathrm{D}$ & 59.00 & 30.39 & 51.5 \\
\hline$E$ & 3.88 & 0.17 & 4.3 \\
\hline $\mathrm{F}$ & 1.59 & 0.46 & 28.9 \\
\hline G & 0.24 & 0.02 & 10.4 \\
\hline $\mathrm{H}$ & 28.20 & 4.17 & 14.8 \\
\hline I & 1.11 & 0.22 & 19.6 \\
\hline $\mathrm{J}$ & 0.06 & 0.01 & 20.9 \\
\hline K & 0.21 & 0.12 & 56.1 \\
\hline $\mathrm{L}$ & 0.31 & 0.09 & 30.6 \\
\hline$M$ & 98.90 & 51.33 & 51.9 \\
\hline Mean & 26.30 & 12.71 & 34.8 \\
\hline $\mathrm{SD}$ & 33.70 & 19.16 & 19.8 \\
\hline
\end{tabular}

increased to $26.3 \times 10^{5} \mathrm{CFU} \mathrm{g}^{-1}$; the mean of the total YPB was $12.7 \times 10^{5} \mathrm{CFU} \mathrm{g}^{-1}$ and constituted $35 \%$ of the total bacteria recovered. Significant differences $(p<0.0001)$ among the total aerobic bacteria, total YPB, and the percent YPB were observed.

All YPB strains were slow growing on $1.5 \%$ CA upon initial isolation, with colony diameters ranging from 1 to $3 \mathrm{~mm}$ after 3 to $5 \mathrm{~d}$ at $20^{\circ} \mathrm{C}$. All were Gramnegative, facultatively anaerobic, non-flagellate rods measuring $0.6-0.8 \times 4-8 \mu \mathrm{m}$. All strains were cytochrome oxidase and catalase positive and non-fermentative (non-reactive) in OF medium with glucose. Seven of 18 strains exhibited gliding motility and 8 displayed penicillin sensitivity. Based on the criteria of Holmes et al. (1984), 11 of the YPB displayed biochemical characteristics resembling Flavobacterium (e.g. failed to exhibit gliding motility) while the remaining strains were similar to those of Flexibacter-Cytophaga. 


\section{Gill lesions of bacterial gill disease}

The most common gross and microscopic lesions observed in natural outbreaks of BGD in Ontario are summarized in Table 2. Every lesion was not always observed in each outbreak. In the mild form of the disease, lamellae were often only swollen, with mild multifocal to diffuse epithelial and chloride cell hypertrophy (Fig. 1). In most cases, congestion of branchial blood vessels was evident, with only a mild interstitial inflammatory infiltrate. However, in one outbreak large numbers of neutrophils and a few mononuclear leukocytes were present within the interstitium of the filaments. Filamentous bacteria were not consistently observed on the surface of the gill epithelium, but when present, they had a focai to muitifocai distribution. They were either aggregated into microcolonies or were closely apposed to the gill tissue as individual fllamentous cells. Occasionally, single cell epithelial degeneration and exfoliation were present. Mild BGD was associated with gill bacterial loadings roughly $10-$ fold greater $\left(\right.$ mean $\left.=1.50 \times 10^{4} \mathrm{CFU} \mathrm{g}^{-1}\right)$ than those recovered from healthy gills.

The moderate form of the disease was also characterized by swollen, eosinophilic lamellar epithelial and chloride cells but had the additional feature of single cell hydropic degeneration and necrosis of the epithelium with exfoliation. Bacteria were scattered in low to moderate numbers; again these were present as microcolonies or as several filamentous organisms closely associated with degenerating cells and organic debris (Fig. 2). Filamentous bacteria were also found within degenerating epithelial and chloride cells (Fig. 3 ). In these instances the inflammatory infiltrate was more prominent within the affected lamellae and the interstitium of the filament. Moderate BGD had approximately 100 -fold more bacteria (mean $=9.57 \times$ $10^{4} \mathrm{CFU} \mathrm{g}^{-1}$ ) associated with the gill tissue compared to healthy gills.

In more severely affected fish, multifocal lamellar clubbing and fusion became apparent (Fig. 4). Moderate hypertrophy and hyperplasia of the epithelial cells were present surrounding the lamellar marginal channel; this usually involved lamellae situated on the distal $1 / 4$ to $1 / 3$ of the filament. Moderate numbers of multifocally distributed filamentous bacteria were evident in section. Occasionally, individual degenerate epithelial or chloride cells were seen sloughing from the lamellar surface. Filamentous bacteria were usually associated with these exfoliating cells; they were also common within degenerate cells still adherent to the basal lamina.

Table 2. Oncorhynchus mykiss. Summary of the most common gross and microscopic gill lesions of intensively cultured salmonids with $B G D$ in relation to the number of bacteria recovered (expressed as CFU $\mathrm{g}^{-1}$ ) on Cytophaga agar. Range of bacteria recovered and the number of outbreaks examined in parentheses

\begin{tabular}{|c|c|c|c|}
\hline $\begin{array}{l}\text { Degree of } \\
\text { severity }\end{array}$ & Gill pathology & Microscopic lesions & $\begin{array}{c}\text { Bacteriology } \\
\text { Mean bacteria recovered }\end{array}$ \\
\hline Mild & $\begin{array}{l}\text { Gill hyperaemia } \\
\text { Filaments mildly swollen } \\
\text { Mild mucus secretion }\end{array}$ & $\begin{array}{l}\text { Mild lamellar epithelial and chloride } \\
\text { cell hypertrophy } \\
\text { Few filamentous bacteria evident } \\
\text { Branchial blood vessels congested }\end{array}$ & $\begin{array}{c}1.50 \times 10^{4} \\
\left(6.32 \times 10^{3}-2.36 \times 10^{4} ; n=2\right)\end{array}$ \\
\hline Moderate & $\begin{array}{l}\text { Gill hyperaemia } \\
\text { Filaments moderately swollen } \\
\text { Moderate mucus secretion }\end{array}$ & $\begin{array}{l}\text { Moderate to severe lamellar epithe- } \\
\text { lial and chloride cell hypertrophy } \\
\text { Mild focal epithelial cell degenera- } \\
\text { tion and necrosis } \\
\text { Moderate numbers of bacteria evi- } \\
\text { dent both on gills and within degen- } \\
\text { erating cells }\end{array}$ & $\begin{array}{c}9.57 \times 10^{4} \\
\left(2.05 \times 10^{4}-2.86 \times 10^{5} ; n=3\right)\end{array}$ \\
\hline Severe & $\begin{array}{l}\text { Widespread clubbing and fusion } \\
\text { of filaments } \\
\text { Mucus hypersecretion and } \\
\text { entrapment of debris } \\
\text { Opercular erosion } \\
\text { Secondary fungal invasion often } \\
\text { apparent }\end{array}$ & $\begin{array}{l}\text { Severe epithelial and chloride cell } \\
\text { hyperplasia and lamellar fusion. } \\
\text { Filamental fusion present, often with } \\
\text { fungal involvement } \\
\text { Severe mucus cell hyperplasia } \\
\text { Large numbers of filamentous bac- } \\
\text { teria evident, often within degener- } \\
\text { ating cells } \\
\text { Marked multifocal epithelial and } \\
\text { chloride cell degeneration and } \\
\text { necrosis }\end{array}$ & 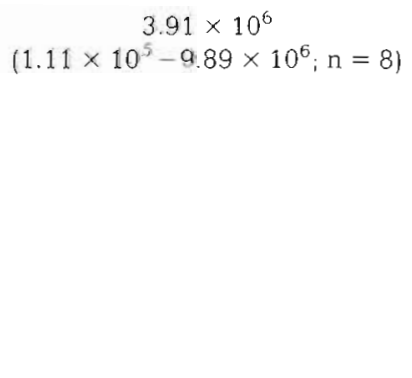 \\
\hline
\end{tabular}


Fig. 1. Oncorhynchus mykiss. Minimal hypertrophy of epithelial and chloride cells associated with filamentous bacteria in a mild case of BGD. Degeneration of several lamellar epithelial cells is also apparent (arrow). H\&E, $\times 40$

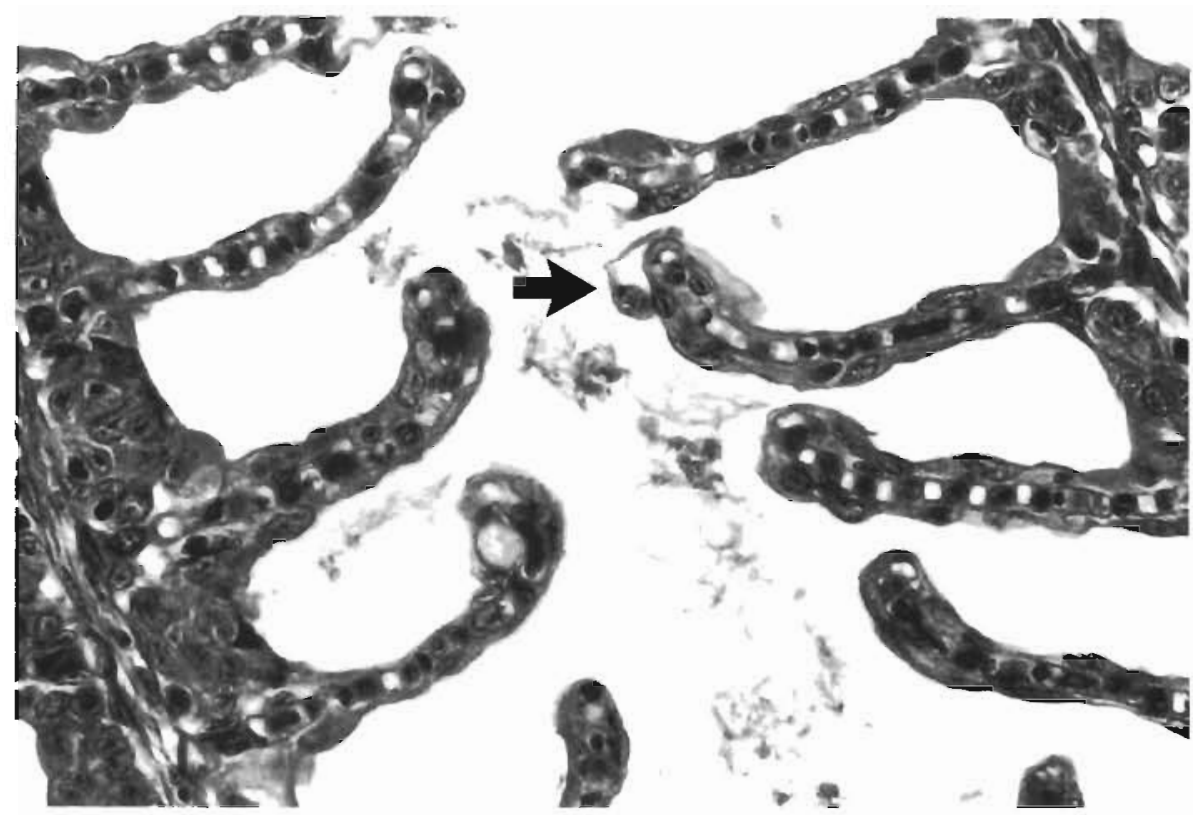

Severe cases of BGD had diffuse lamellar epithelial hyperplasia with extensive lamellar fusion and, occasionally, filamental fusion. Again many blood vessels were congested, often with the marginal vessels of the lamellae extremely dilated. This usually involved lamellae on the distal portions of the filaments, but proximal regions were also affected in severe cases. In either case, total occlusion of the interlamellar space occurred, often with encapsulated foci containing necrotic epithelial cells, filamentous bacteria, and organic debris (Fig. 5). Occasionally protozoan and fungal organisms were observed but were not identified further Large amounts of PAS positive material were also present within the encapsulated foci, almost always associated with exfoliated cells, bacteria, and organic debris. Severe BGD was associated with approximately 1000 -fold increase in bacteria (mean $=$ $3.91 \times 10^{6} \mathrm{CFU} \mathrm{g} \mathrm{g}^{-1}$ ) recovered from diseased gills compared to healthy gills.

Severely affected areas, characterized by extensive hyperplasia of the lamellar epithelium, were associated with large numbers of adherent, filamentous bacteria.
Fig. 2. Oncorhynchus mykiss. Moderate outbreak of BGD showing lamellar epithelial and chloride cell hypertrophy associated with filamentous bacteria (arrow). Exfoliation of degenerate cells (DC) into the interlamellar space is also apparent. $H \& E_{1} \times 100$

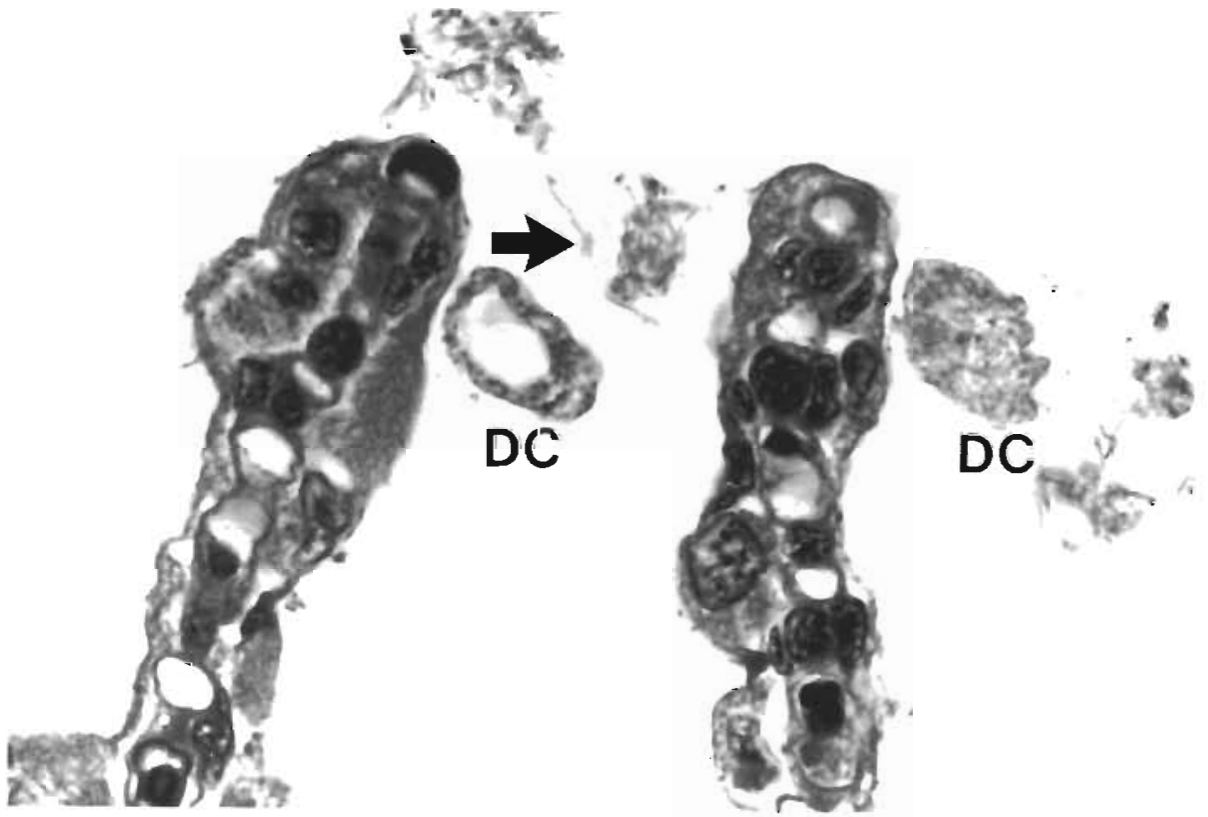



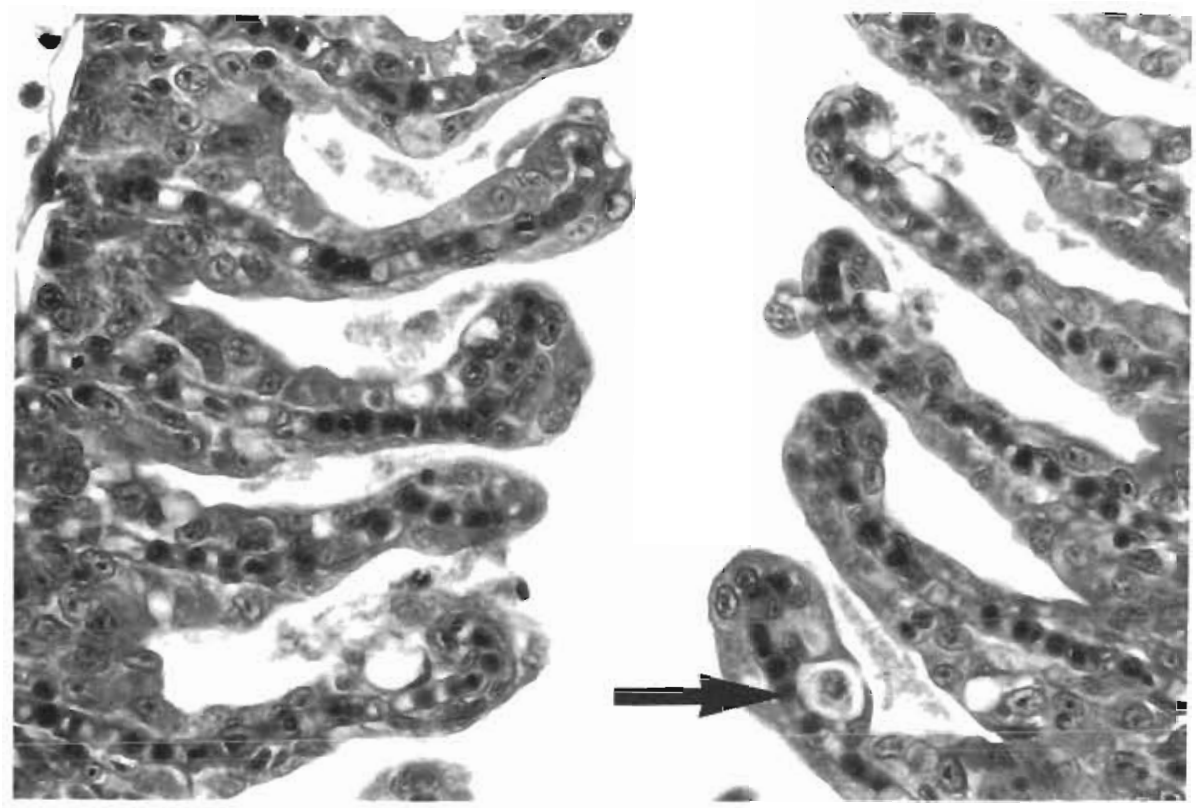

Fig. 3. Oncorhynchus mykiss. Lamellar epithelial hypertrophy and hyperplasia with degenerative changes of the epithelium. Filamentous bacteria are also present within degenerating cell.s (arrow). H\&E, $\times 40$

The hyperplastic epithelium appeared spongiform, with relatively large numbers of mononuclear leukocytes and a few neutrophils present throughout the lamellar and filamental interstitium. Eosinophilic granulocytes were occasionally found within the hyperplastic epithelium, but they were usually restricted to a region in close proximity to the central venous sinus. PAS stained sections indicated an increase in the number of goblet cells associated with regions of hyperplasia and fusion.

Focal to multifocal lamellar telangiectasia (aneurisms) along the entire filament was occasionally present in severe outbreaks. Degradation of the erythrocytes within ectatic vessels was seen in one outbreak, with the deposition of a hemosiderin-like pigment occurring within the affected lamellae. A mononuclear cell infiltrate (probably macrophages) accompanied these changes. In outbreaks where large amounts of organic debris were evident in the gills, a few microcolonies of short, fat, Gram-negative rods were occasionally present; otherwise other pathogens were not observed. Secondary fungal involvement was also evident in a few severe cases. These presented as necrotic wedge-shaped foci, predominantly affecting the distal portion of the filaments. Several filaments were often fused distally with large numbers of fungal hyphae invading the necrotic tissue.

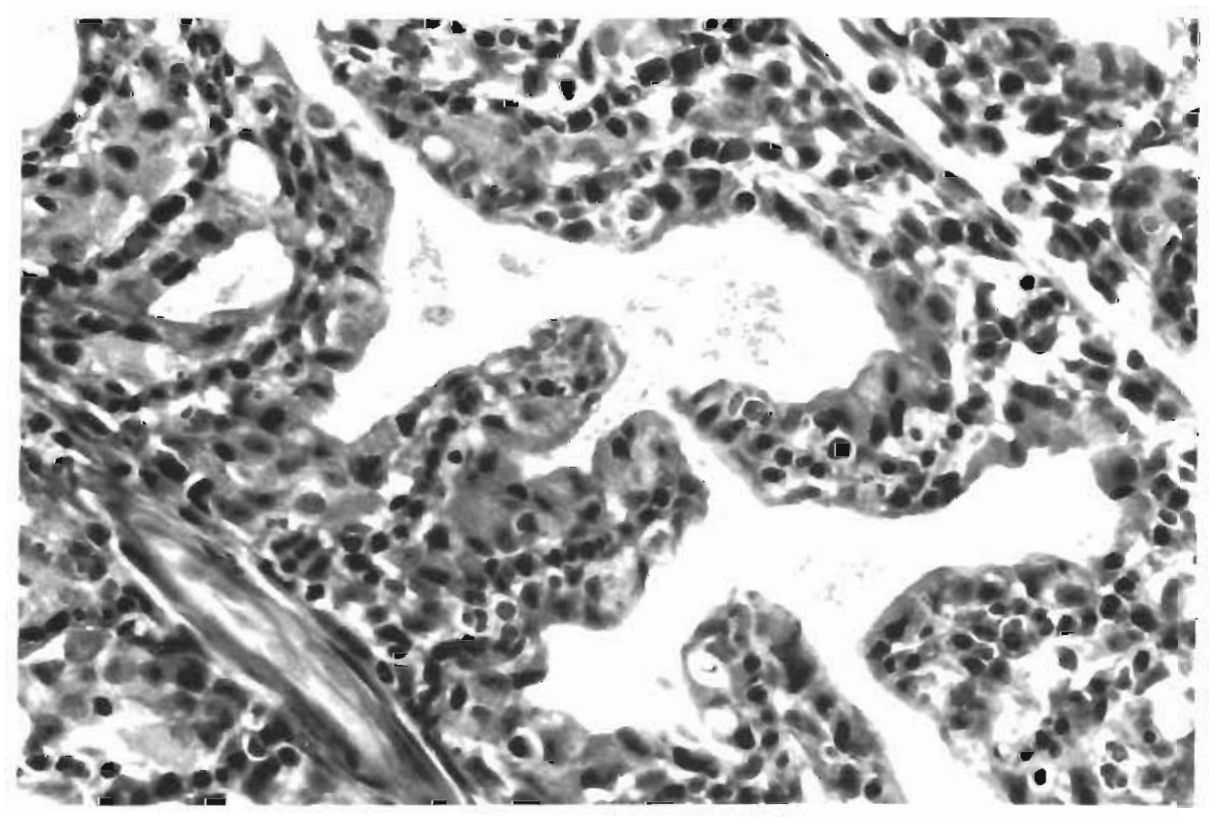

Fig. 4. Oncorhynchus mykiss. More severe case of BGD showing multifocal interlamellar hyperplasia and fusion of lamellae. Large numbers of filamentous bacteria are also apparent between lamellae and filaments $H \& E, \times 40$ 


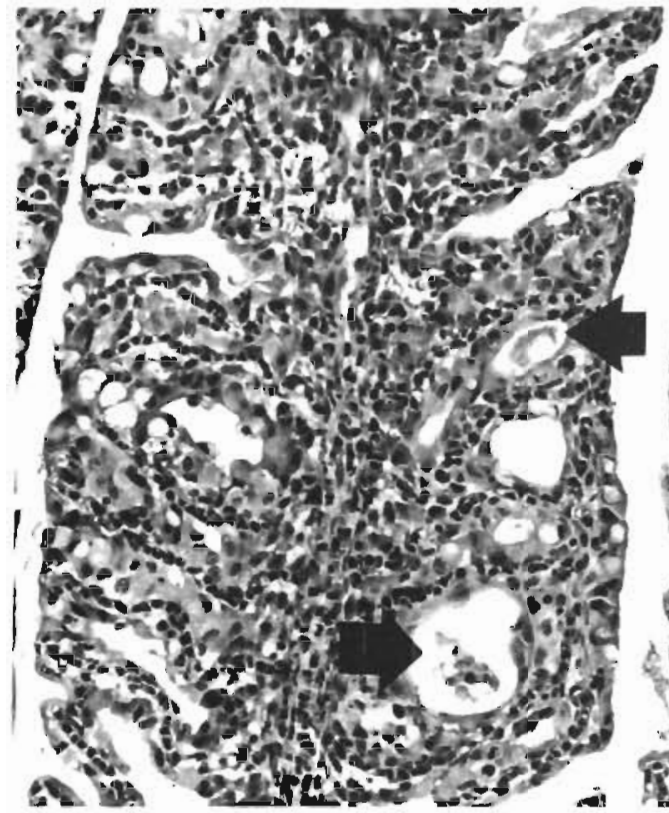

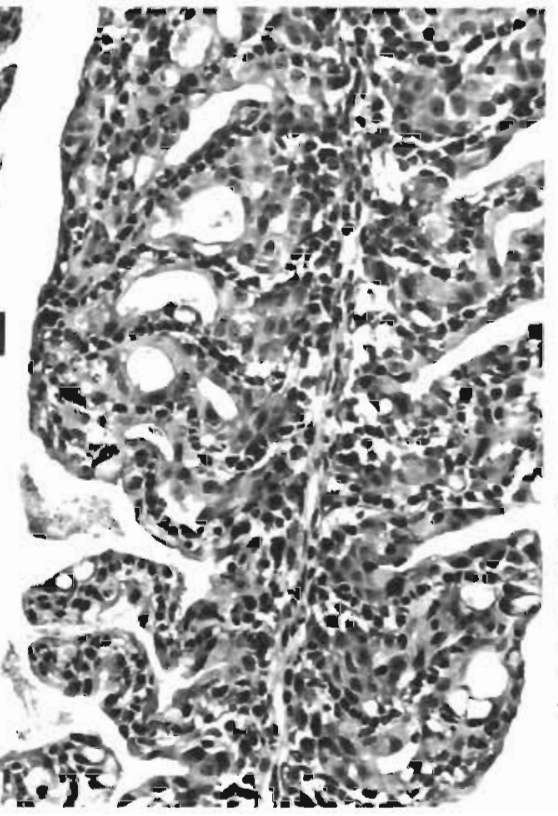

Fig. 5. Oncorhynchus mykiss. Severe case of BGD showing widespread spongiotic, hyperplastic epithelium and lamellar fusion. Necrotic debris and filamentous bacteria seen in several encapsulated foci (arrows). A mononuclear interstitial infiltrate is also evident. $\mathrm{H} \& \mathrm{E}, \times 20$

\section{Lesions in other organs}

With the exception of the liver and pseudobranch, all other organs consistently appeared normal. In a few outbreaks, mild to moderate epithelial hyperplasia was apparent, involving the dorsal aspect of the buccal chamber immediately adjacent to the pseudobranch and gill arches, but filamentous bacteria and organic debris were usually not present.

In one outbreak ( $B)$, zonal changes were seen in the liver of a few fish. Single cell degeneration, necrosis and atrophy of hepatocytes surrounding the central vein were apparent, resulting in a reticulated appearance to the liver. An inflammatory response did not accompany this change. Hyperplasia of the epithelium covering the pseudobranch was present in several outbreaks, occasionally associated with filamentous bacterial microcolonies. Pseudobranchial aneurisms were occasionally seen and in one case, there was noninvasive fungal involvement of the pseudobranchial epithelium, probably as an extension from adjacent gill tissue.

\section{Statistical analysis of microscopic lesions and bacterial recovery}

The mean of each histological lesion score from each outbreak and, where appropriate, the mean number of bacteria recovered (i.e. from outbreaks with gills sampled individually), are summarized in Table 3. These scores were used to calculate the Spearman correlation coefficients between all criteria. Spearman correlation coefficients of all possible combinations of histological lesion scores against the total bacteria recovered from the diseased gills (Table 4) indicated a strong correlation between the presence of hyperplasia and fusion, and between the histological presence of bacteria and the actual number of bacteria recovered. It also appears that the histological presence of bacteria and the actual number recovered are strongly associated with hyperplasia. A relatively strong correlation appeared to exist among fusion, the number of bacteria recovered, and the number of bacteria observed histologically.

\section{DISCUSSION}

We have shown that bacterial gill disease in Ontario hatcheries is associated with an increase in numbers of both the aerobic and the yellow pigmented bacteria (YPB) on the gills; in both cases, numbers were approximately 1000 times greater in severely diseased gills than in those recovered from clinically healthy fish. Our findings are in agreement with those of other workers (Anderson \& Conroy 1969, Bullock 1972, Kimura et al. 1978. Wakabayashi et al. 1980) who have also implicated YPB in BGD elsewhere.

In some outbreaks, however (e.g. Outbreaks E, G, and $\mathrm{H}$ ), $\mathrm{YPB}$ were not the numerically dominant isolates, and this raises the likelihood that filamentous bacteria other than YPB may also be associated with BGD in Ontario. This would help explain the seemingly anomalous low recovery of YPB from some outbreaks, even though large numbers of filamentous bacteria were observed in section. It is also possible that homogenization of gills in saline may have selected for salt-tolerant bacteria, or that the bacteria may have had reduced viability, perhaps due to nonspecific defense 
Table 3. Oncorhynchus mykiss. Mean histological gill lesion scores and total bacteria recovered from gills in 13 naturally occurring BGD outbreaks in Ontario. Bacteria recovered $\mathrm{g}^{-1}$ wet gill tissue on Cytophaga agar

\begin{tabular}{|c|c|c|c|c|c|}
\hline \multirow[t]{2}{*}{ Outbreak } & \multirow[t]{2}{*}{ Classification } & \multicolumn{3}{|c|}{ Mean histological gill score } & \multirow{2}{*}{$\begin{array}{l}\text { Bacteria recovered } \\
\qquad\left(\mathrm{CFU} \mathrm{g}^{-1}\right)\end{array}$} \\
\hline & & Fusion & Hyperplasia & H bacteria ${ }^{\mathrm{a}}$ & \\
\hline A & Severe & 2.20 & 1.20 & 2.60 & $4.53 \times 10^{6}$ \\
\hline B & Severe & 3.00 & 2.00 & 3.00 & $9.14 \times 10^{6}$ \\
\hline $\mathrm{C}$ & Severe & 3.00 & 2.00 & 2.00 & $1.19 \times 10^{6}$ \\
\hline $\mathrm{D}$ & Severe & 3.00 & 3.00 & 2.67 & $5.90 \times 10^{6}$ \\
\hline$E$ & Severe & 2.00 & 1.83 & 3.00 & $3.88 \times 10^{5}$ \\
\hline $\mathrm{F}$ & Severe & 2.50 & 1.90 & 1.80 & $1.59 \times 10^{5}$ \\
\hline $\mathrm{G}$ & Mild & 0.00 & 1.00 & 0.00 & $2.36 \times 10^{4}$ \\
\hline $\mathrm{H}$ & Moderate & 0.60 & 1.60 & 2.20 & $2.82 \times 10^{6}$ \\
\hline I & Severe & 2.80 & 1.80 & 2.50 & $1.11 \times 10^{5}$ \\
\hline $\mathrm{J}$ & Mild & 0.83 & 0.83 & 0.00 & $6.32 \times 10^{3}$ \\
\hline$K$ & Moderate & 2.00 & 0.50 & 0.50 & $2.05 \times 10^{4}$ \\
\hline $\mathrm{L}$ & Moderatc & 1.50 & 1.50 & 0.20 & $3.05 \times 10^{4}$ \\
\hline M & Severe & 2.83 & 2.33 & 3.00 & $9.89 \times 10^{6}$ \\
\hline Mean & & 2.02 & 1.65 & 1.81 & $2.63 \times 10^{6}$ \\
\hline$S D$ & & 1.01 & 0.66 & 1.20 & $3.37 \times 10^{6}$ \\
\hline
\end{tabular}

Table 4. Oncorhynchus mykiss. Spearman correlation coefficients among histological criteria obtained from 13 BGD outbreaks affecting commercially reared salmonids in Ontario and total bacteria recovered $g^{-1}$ gill tissue. $P$ values in parentheses

\begin{tabular}{|lcccc|}
\hline Criteria & Fusion & $\begin{array}{c}\text { Hyper- } \\
\text { plasia }\end{array}$ & H bacteria & $\begin{array}{c}\text { Bacteria } \\
\text { recovered }\end{array}$ \\
\hline Fusion & 1.00 & 0.80 & 0.64 & 0.66 \\
& $(0.00)$ & $(0.001)$ & $(0.02)$ & $(0.01)$ \\
Hyperplasia & & 1.00 & 0.71 & 0.78 \\
& & $(0.00)$ & $(0.01)$ & $(0.002)$ \\
H bacteria & & & 1.00 & 0.85 \\
& & & $(0.00)$ & $(0.0002)$ \\
Bacteria & & & 1.00 \\
recovered & & & $0.00)$ \\
a Histological presence of bacteria & & \\
\hline
\end{tabular}

properties of the gill mucus or even to previous (unreported) prophylactic treatment by the farmers before submission to the laboratory It is also possible that some strains of filamentous bacteria grow slowly or even fail to grow on Cytophaga agar and subsequently were overgrown by other more non-fastidious bacteria. Another anomaly was the presence in whole-mounts of large numbers of filamentous bacteria, while histologically, gill lesions were not prominent. Possible explanations for this include firstly arch-to-arch variability of both bacterial colonization and distribution of lesions, or secondly the stage of the disease, with colonization preceding detectable (at the light microscope level) morphological change.
The strong statistical relationship between the presence of filamentous bacteria, both microscopically and on culture, and the extent of fusion and hyperplasia, suggests a strong association between clinical BGD and the presence of filamentous bacteria. The possibility still remains, however, that the bacteria are merely taking advantage of a mucosal surface previously altered by some as yet undetermined factor. Although poor water quality (particularly elevated ammonia) has been implicated in producing architectural changes similar to those described here for BGD (Burrows 1964, Smith \& Piper 1975, Peters et al. 1984), it is now generally accepted that ammonia salts, under several experimental regimes, do not inevitably produce gill hyperplasia (Smart 1976, Mitchel \& Cech 1983, Daoust \& Ferguson 1984, Soderberg 1985). In many of the outbreaks examined in this study, clinical histories failed to implicate a water quality problem, including high ammonia levels, and water samples obtained from several outbreaks confirmed this (Ostland 1989). Accordingly, it is felt that ammonia probably did not play a direct role in the overall pathogenesis of BGD in the current outbreaks, although this merits further study. It is possible that another water-borne irritant or excretory product, perhaps fecal proteases, could alter the chemical consistency of the branchial mucus (Roberts 1978), facilitating attachment of water-borne bacteria or allowing a normal gill inhabitant to dominate and displace other components of the existing flora. Further studies are required to increase our understanding of water chemistry and its effect on the bacterial densities on the gills and in water preceding an outbreak of $B G D$, and on the attachment mechanisms of the bacteria. 
This study found that mild to moderate degeneration, necrosis, and exfoliation of lamellar epithelium were frequently associated with the architectural changes and with the filamentous bacteria. This is in contrast to the findings of Wakabayashi \& Iwado (1985) who emphasized that epithelial necrosis was not a feature in the BGD outbreaks that they examined. BGD is considered by some to be largely a proliferative entity which results from the irritating effects of a hyperplasia inducing factor' secreted by the bacterium (Kudo \& Kimura 1983). This seems an unnecessarily complicated hypothesis, especially when necrosis is a feature of the early stage of the disease. Necrosis by itself would normally be expected to lead to many of the changes seen in BGD (for example hyperplasia and fusion), especially if the bacteria persist

In addition to being found on the surface of the gills, filamentous bacteria were also seen within degenerating epithelial and chloride cells from several outbreaks in this study. Similar observations were noted in a naturally occurring outbreak of BGD affecting goldfish (Ostland et al. 1989). Bacteria within degenerating cells may offer a portal of entry and potentially result in a systemic form of the disease. 'Myxobacteria' have been recovered from other organs in addition to the gills in salmonids affected with severe BGD (Rucker et al. 1952, 1953, Bullock 1972). This contrasts with the opinion of Anderson \& Conroy (1969) and Ototake \& Wakabayashi (1985) that 'myxobacteria' and Flavobacterium strains associated with BGD do not invade host gill tissue. Thus, YPB associated with BGD may become systemic (like Flexibacter columnaris), although more work is needed to determine to what extent.

The characterization and identification of the YPB from $B G D$ in Ontario are presently being investigated further. YPB recovered from BGD are considered to be members of the genera Flexibacter and Cytophaga (Anderson \& Conroy 1969, Bullock 1972, Snieszko 1981) but a filamentous Flavobacterium has also been described from BGD outbreaks in Japan and Oregon, USA (Wakabayashi et al. 1980) and Hungary (Farkas 1985). It appears that YPB from salmonid BGD in Ontario also fall within the above taxonomic categories, based on the current methods of identification (Holmes et al. 1984). The antigenic and taxonomic relationships between Ontario YPB and other YPB recovered from salmonid $B G D$ (Wakabayashi et al. 1980 ) are presently under investigation.

Acknowledgements. The authors thank Drs J.S. Lumsden and $M$. Thorburn for reviewing the manuscript. The Fish Pathology Laboratory is partially funded by the Ontario Ministry of Agriculture and Food.

\section{LITERATURE CITED}

Amend, D. F. (1982). Columnaris (Flexibacter columnaris) disease of freshwater fishes and a brief review of other flexibacterial diseases of fish. In: Anderson, D. P., Dorson, M., Dubourget, Ph. (eds.) Antigens of fish pathogens: development and production for vaccines and serodiagnostics. Coll. Found. Marcel Merieux, Lyon, France, p. $139-151$

Anacker, R. L., Ordal, E. J. (1959). Studies on the myxobacterium Chondrococcus columnaris. I. Serological typing. J. Bact. 78: 25-32

Anderson, J. I. W. Conroy, D. A. (1969). The pathogenic myxobacteria with special reference to fish diseases. J. appl. Bact. 32: 30-39

Bullock, G. L. (1972). Studies on selected myxobacteria pathogenic forfishes and on bacterial gill disease in hatchery reared salmonids. U.S. Fish Wildl. Serv., Tech. Pap. 86: 1-30

Burrows, R. E. (1964). Effects of accumulated excretory products on hatchery reared salmonids. U.S. Fish. Wildl. Serv. Res. Rep. 66: 1-12

Christensen, P. (1977). The history, biology and taxonomy of the Cytophaga group. Can. J. Microbiol. 23: 1599-1653

Daoust, P. Y., Ferguson, H. W. (1983). Gill diseases of cultured salmonids in Ontario. Can. J. comp. Med. 47: 358-362

Daoust, P. Y., Ferguson, H. W. (1984). The pathology of chronic ammonia toxicity in rainbow trout, Salmo gairdneri Richardson. J. Fish Dis. 7: 199-205

Daoust, P. Y., Ferguson, H. W. (1986), Potential for recovery in nodular gill disease of rainbow trout, Salmo gairdnen Richardson. J. Fish Dis. 9: 313-318

Farkas, J. (1985). Filamentous Flavobacterium sp. isolated from gill diseases in cold water. Aquaculture 44:1-10

Holmes, B., Owen, R. J., McMeekin, T H. (1984). Genus Flavobacterium. In: Krieg, N. R., Holt, J. G. (eds.) Bergey's manual of systematic bacteriology 1. Williams and Wilkens, Baltimore, p. 353-361

Horsley, R. W. (1977). A review of the bacterial flora of teleosts and elasmobranchs, including methods for its analysis. J. Fish Biol. 10: 529-553

Kimura, N., Wakabayashi, H., Kudo, S. (1978). Studies on bacterial gill disease in salmonids. I. Selection of the bacterium transmitting gill disease. Fish Path. 12: 233-242

Kudo, S., Kimura, N (1983). Extraction of a hyperplasiainducing factor. Bull. Jap. Soc. scient. Fish. 49: 1777-1782

Laurent, P. (1984). Gill internal morphology. In: Hoar, W. S. Randall, D. J. (eds.) Fish physiology. Academic Press, London, p. 73-183

Mitchel, S. J., Cech, J. J. Jr (1983). Ammonia caused gill damage in channel catfish (Ictalurus punctatus): confounding effects of residual chlorine. Can. J. Fish. aquat. Sci. 40: 242-247

Ostland, V. E. (1989). Bacterial gill disease of salmonids: A description and definition for the disease in Ontario hatcheries. MSc. Thesis, University of Guelph, Guelph, Ontario

Ostland, V. E., Ferguson, H. W., Stevenson, R. M. W. (1989). Case report: bacterial gill disease in goldfish Carrasias auratus. Dis. aquat. Org. 6: 179-184

Ototake, M., Wakabayashi, H. (1985). Characteristics of extracellular products of Flavobacterium sp., a pathogen of bacterial gill disease. Fish Path 20: 167-171

Peters, G., Hoffman, R., Klinger, H. (1984). Environment induced gill disease of cultured rainbow trout (Salmo gairdneri). Aquaculture 38: 105-126

Roberts, R. J. (1978). The pathophysiology and systemic pathology of teleosts. In: Roberts, R. J. (ed.) Fish pathology. Bailliere-Tindall, London, p. 55-91 
Rucker, R. R., Earp, B. J., Ordal, E. J. (1953). Infectious diseases of Pacific salmon. Trans. Am. Fish. Soc. 83 $297-312$

Rucker, R. R., Johnson, H. E., Kaydas, G. M. (1952). An intern report on gill disease. Prog. Fish Cult. 14: 10-14

SAS Institute Incorporated (1985). SAS Users Guide: statistics. Version 5 edn. SAS Institute Incorporated, Cary, North Carolina

Smart, G. R. (1976). The effect of ammonia exposure on gill structure of rainbow trout (Salmo gairdneri). J. Fish Biol. 8: $471-475$

Smith, C. E., Piper, R. G. (1975). Lesions associated with chronic exposure to ammonia. In: Ribelin, W. E., Migaki, G. W. (eds.) The pathology of fishes. University Wisconsin Press, Maddison, p. 497-514

Responsible Subject Editor: Dr T. Evelyn, Nanaimo, B.C., Canada
Snieszko, S. F. (1981). Bacteria gill disease of freshwater fishes. U.S. Fish Wildl. Serv. Fish Dis. Leafl. 62:1

Soderberg, R. W (1985). Histopathology of rainbow trout, Salmo gairdneri Richardson, exposed to diumally fluctuating un-ionized ammonia levels in static water ponds. J. Fish Dis. 8: 57-64

Wakabayashi, H., Egusa, S., Fryer, J. L. (1980). Characteristics of filamentous bacteria isolated from a gill disease in salmonids. Can. J. Fish. Aquat. Sci. 37-1499-1504

Wakabayashi, $H_{\text {. }}$ Iwado, $T$ (1985). Effects of bacterial gill disease on the respiratory function of juvenile rainbow trout. In: Ellis, A. E. (ed.) Fish and shellfish pathology Academic Press, London, p. 153-160

Wood, E. M., Yasutake, W T. (1957). Histopathology of fish. V Gill disease. Prog. Fish Cult. 19: 7-13

Manuscript first received: October 27, 1989

Revised version accepted: June 8, 1990 